\title{
Microwaves: a Novel Approach to SARS-CoV-2 Genome Extraction
}

\section{Marta Elena Álvarez-Argüelles}

Hospital Universitario Central de Asturias

\section{Susana Rojo-Alba}

Hospital Universitario Central de Asturias

Gabriel Martin ( $\nabla$ gabrielmartinrguez1994@gmail.com )

Hospital Universitario Central de Asturias https://orcid.org/0000-0003-0304-6250

\section{Zulema Pérez-Martínez}

Hospital Universitario Central de Asturias

\section{Cristian Castelló-Abietar}

Hospital Universitario Central de Asturias

Jose Antonio Boga

Hospital Universitario Central de Asturias

\section{Santiago Melón}

Hospital Universitario Central de Asturias

\section{Research Article}

Keywords: SARS-CoV-2, COVID-19, genome extraction, heat extraction, microwaves

Posted Date: November 30th, 2021

DOI: https://doi.org/10.21203/rs.3.rs-464126/v1

License: (c) (1) This work is licensed under a Creative Commons Attribution 4.0 International License.

Read Full License 


\section{Abstract}

On this study an innovative approach to the heat extraction has been tested: the use of microwaves, which can decrease dramatically the time needed to do the genome extraction. The method can obtain the virus with enough quality to assure the identification by $q(\mathrm{RT})-\mathrm{PCR}$ and minimize procedures and contaminations.

\section{Main Text}

With the global SARS-CoV2 pandemic, the need of quick and efficient techniques to process samples has become an aim for all the clinical laboratories around the world. Several methods like heat extraction can be a clear alternative to improve times of procedure at the time of doing the genome extraction (1-4).

On this study an innovative approach to the heat extraction has been tested: the use of microwaves, which can decrease dramatically the time needed to do the genome extraction. The method can obtain the virus with enough quality to assure the identification by $q(R T)-P C R$ and minimize procedures and contaminations.

To check this hypothesis, a set of 43 nasopharyngeal samples were extracted by five different methods: two of them using chaotropic reagents, and three based on heat extraction. The two methods that use reagents were automatic MagNa Pure 96 (Roche, Ginebra) taken as reference, and the "Bikop" method developed on our laboratory previously (3). Both procedures were carried with $200 \mu \mathrm{L}$ of each sample.

About the three methods based on heat extraction, one consistent just in a heat application at $98^{\circ} \mathrm{C}$ for 10 minutes as the normal method. Second method was based on the addition of proteinase K (pK) to favour denaturalization before heat application; for this method, the heat application had two steps: first at $56^{\circ} \mathrm{C}$ during 5 minutes followed by other at $98^{\circ} \mathrm{C}$ for 10 minutes (5-7). The last one method of the heat extraction was the use of microwaves. This method was performed on a microwave oven Schneider SMW205 (Schneider Electric, Llanera, Spain), during 1 minute at $800 \mathrm{~W}$ and $2450 \mathrm{MHz}$ of microwave frequency. For all these protocols, the heat application was followed by a cooling step on ice for 5 minutes. A volume of $100 \mu \mathrm{L}$ of each sample were used.

All extracted samples were tested with a multiple qRT-PCR directed to two regions of the SARS-CoV 2 genome (Orf1 $1 \mathrm{ab}$ and $\mathrm{N}$ gene). Briefly, $5 \mu \mathrm{l}$ of sample, previously extracted by any of the tested methods, were added to $10 \mu \mathrm{l}$ of TaqMan Fast 1-Step Master Mix (Life technologies, Carlsbad, CA) supplemented with a mixture of primers (Thermo Fisher Scientific, Walthman, MA) and taqman MGB probes (Applied Biosystems, Foster City, CA) which were the same conditions as used in reference 3. Amplification and subsequent analysis were carried out using the Applied Biosystems 7500 Real-time PCR System (Applied Biosystems). The cycling protocol was as follows: $\left(50^{\circ} \mathrm{C}, 20 \mathrm{~min} ; 95^{\circ} \mathrm{C}, 5 \mathrm{~min} ; 45 \mathrm{cycles}\right.$ of $95^{\circ} \mathrm{C}, 10 \mathrm{sec}$; $55^{\circ} \mathrm{C}, 15 \mathrm{sec}$ and $60^{\circ} \mathrm{C}, 30 \mathrm{sec}$ ). 
The cycle threshold for each sample on each procedure and the statistical results, like sensitivity, of the total and broken down into less than and greater or equal to Ct 30 are shown in tables 1 and 2.

These data show that all the protocols tested are over $95 \%$ of sensitivity, except for the microwaves method, that almost get $90 \%$. Despite this exception, differences are not significant.

Viral load, reflected as $\mathrm{Ct}$, has influence on these results: when a threshold was made in $\mathrm{Ct}$, all procedures analysed were sensitive enough for samples which were amplified under 30 cycles, with results over $95 \%$ for every method. Over $30 \mathrm{Ct}$, or even more, over $32 \mathrm{Ct}$, a decrease in sensitivity happens, especially on microwaves method. As amplification of these samples can be confuse according to their capacity to infect, results over this Ct should be taken in care in any case. On the other hand, it is noted that manual methods have higher variance than automatized reference methods, as ranges of each sample are higher than in MP96 method. Special care must be token when manual methods are performed.

In conclusion, the results confirm that heat extraction can be implemented in a clinical laboratory as a fast method to get samples ready for the $q(R T)$-PCR and offer a sooner detection. The use of microwaves method can be the fastest way of extraction when the number of samples exceed the capacity of the laboratory to process them in time, specially when high incidence is noted, in order to prevent the elongation of the contagious chain.

\section{Declarations}

\section{Acknowledgements}

Thanks to ASCOL (Asturiana de Control Lechero) for their financial support for this research.

\section{Declaration of Interest Statement}

Authors declare no potential conflicts of interest.

\section{Ethical Committee}

This study was approved by Comité de Ética de la Investigación del Principado de Asturias with code CEImPA 2021.188

\section{References}

1. Merindol N, Pépin G, Marchand C, et al. SARS-CoV-2 detection by direct rRT-PCR without RNA extraction. J Clin Virol. 2020;128:104423. doi:10.1016/j.jcv.2020.104423

2. Mancini F, Barbanti F, Scaturro M, et al. Laboratory management for SARS-CoV-2 detection: a userfriendly combination of the heat treatment approach and rt-Real-time PCR testing. Emerg Microbes Infect. 2020;9(1):1393-1396. doi:10.1080/22221751.2020.1775500 
3. Martín G, Rojo-Alba S, Castelló-Abietar C, et al. Comparison of in-house SARS-CoV-2 genome extraction procedures. A need for COVID-19 pandemic. Research Square preprint 2021 Mars 15. doi:10.21203/rs.3.rs-214704/v1

4. Smyrlaki, I., Ekman, M., Lentini, A. et al. Massive and rapid COVID-19 testing is feasible by extractionfree SARS-CoV-2 RT-PCR. Nat Commun 11, 4812 (2020). doi:10.1038/s41467-020-18611-5

5. García F, Melón S, Navarro D, et al. Organización del dignóstico de SARS-CoV-2 y estrategias de optimización. SEIMC protocol 14/10/2020 https://seimc.org/contenidos/documentoscientificos/recomendaciones/seimc-rc-2020-COVID19OrganizacionDiagnostico.pdf

6. Mallmann L, Schallenberger K, Demolliner M, et al. Pre-treatment of the clinical sample with Proteinase $\mathrm{K}$ allows detection of SARSCoV-2 in the absence of RNA extraction. bioRxiv preprint 2020 May 9. doi: 10.1101/2020.05.07.083139

7. Vogels CBF, Brackney DE, Wang J, et al. SalivaDirect: Simple and sensitive molecular diagnostic test for SARS-CoV-2 surveillance. medRxiv preprint. 2020 Aug 4. doi:10.1101/2020.08.03.20167791

\section{Tables}


Table 1

Sensitivity, mean, range, IC95\% and p-value for the different methods tested

Extraction with reagents Heat Extraction

\begin{tabular}{|c|c|c|c|c|c|}
\hline & MP96 & Bikop & Normal & With pK & Microwaves \\
\hline \multicolumn{6}{|l|}{ Total } \\
\hline Positives & 43 (100\%) & $41(95,34 \%)$ & $41(95,34 \%)$ & $41(95,34 \%)$ & $38(88,37 \%)$ \\
\hline$\overline{\mathrm{x}} \pm \sigma$ & $29,07 \pm 4,44$ & $27,29 \pm 4,36$ & $26,39 \pm 4,57$ & $25,58 \pm 4,02$ & $27,31 \pm 5,02$ \\
\hline Range & $(21-34)$ & $(15-37)$ & $(17-36)$ & $(18-35)$ & $(17-37)$ \\
\hline IC95\% & $(27,86-30,28)$ & $(25,99-28,59)$ & $(25,03-27,75)$ & $(24,38-26,78)$ & $(25,81-28,81)$ \\
\hline$p$ value & - & 0,20 & 0,21 & 0,21 & 0,04 \\
\hline \multicolumn{6}{|l|}{$\mathrm{Ct}<30$} \\
\hline Positives & $21(100 \%)$ & $20(95,24 \%)$ & $21(100 \%)$ & $21(100 \%)$ & $20(95,24 \%)$ \\
\hline$\overline{\mathrm{x}} \pm \sigma$ & $25,57 \pm 2,68$ & $25,15 \pm 4,30$ & $24,14 \pm 4,22$ & $24,85 \pm 4,14$ & $26,3 \pm 5,39$ \\
\hline Range & $(21-29)$ & $(15-32)$ & $(17-31)$ & $(18-30)$ & $(17-35)$ \\
\hline IC95\% & $(24,43-26,71)$ & $(23,31-26,99)$ & $(22,33-25,95)$ & $(23,08-26,62)$ & $(23,99-28,61)$ \\
\hline$p$ value & - & 0,23 & 0,45 & 0,49 & 0,45 \\
\hline \multicolumn{6}{|l|}{$\mathrm{Ct} \geq 30$} \\
\hline Positives & $22(100 \%)$ & $21(95,45 \%)$ & $20(90,91 \%)$ & $20(90,91 \%)$ & $18(81,82 \%)$ \\
\hline$\overline{\mathrm{x}} \pm \sigma$ & $32,4 \pm 1,37$ & $29,33 \pm 3,40$ & $28,75 \pm 3,70$ & $26,35 \pm 3,86$ & $28,44 \pm 4,45$ \\
\hline Range & $(30-34)$ & $(23-37)$ & $(22-36)$ & $(21-35)$ & $(20-37)$ \\
\hline IC95\% & $(31,83-32,97)$ & $(27,91-30,75)$ & $(27,20-30,30)$ & $(24,74-27,96)$ & $(26,58-30,30)$ \\
\hline$p$ value & - & 0,19 & 0,09 & 0,10 & 0,02 \\
\hline
\end{tabular}


Table 2

Cycle threshold for each sample by genome extraction procedure

\begin{tabular}{|c|c|c|c|c|c|}
\hline \multirow[b]{2}{*}{ Sample } & \multicolumn{2}{|c|}{ Extraction with reagents } & \multicolumn{3}{|c|}{ Heat Extraction } \\
\hline & MP96 & Bikop & Normal & With pK & Microwaves \\
\hline $1^{\circ}$ & 21 & 27 & 21 & 22 & 19 \\
\hline $2^{\circ}$ & 21 & 20 & 17 & 18 & 17 \\
\hline $3^{\circ}$ & 23 & 15 & 18 & 21 & 21 \\
\hline $4^{\circ}$ & 23 & 21 & 24 & 30 & 29 \\
\hline $5^{\circ}$ & 23 & 28 & 26 & 30 & 26 \\
\hline $6^{\circ}$ & 23 & 19 & 18 & 18 & 18 \\
\hline $7^{\circ}$ & 24 & 25 & 23 & 27 & 32 \\
\hline $8^{\circ}$ & 24 & 27 & 30 & 30 & 27 \\
\hline $9^{\circ}$ & 25 & 25 & 23 & 27 & 31 \\
\hline $10^{\circ}$ & 25 & 27 & 23 & 29 & 29 \\
\hline $11^{\circ}$ & 25 & 29 & 30 & 24 & 24 \\
\hline $12^{\circ}$ & 26 & 25 & 23 & 29 & 29 \\
\hline $13^{\circ}$ & 27 & 25 & 21 & 21 & 35 \\
\hline $14^{\circ}$ & 27 & 30 & 28 & 26 & 32 \\
\hline $15^{\circ}$ & 28 & 31 & 29 & 24 & 0 \\
\hline $16^{\circ}$ & 28 & 25 & 29 & 23 & 34 \\
\hline $17^{\circ}$ & 28 & 22 & 21 & 21 & 22 \\
\hline $18^{\circ}$ & 29 & 22 & 21 & 21 & 24 \\
\hline $19^{\circ}$ & 29 & 0 & 25 & 30 & 26 \\
\hline $20^{\circ}$ & 29 & 28 & 26 & 22 & 21 \\
\hline $21^{\circ}$ & 29 & 32 & 31 & 29 & 30 \\
\hline $22^{\circ}$ & 30 & 26 & 28 & 21 & 24 \\
\hline $23^{\circ}$ & 30 & 23 & 23 & 22 & 26 \\
\hline $24^{\circ}$ & 30 & 28 & 26 & 24 & 25 \\
\hline $25^{\circ}$ & 31 & 28 & 0 & 29 & 31 \\
\hline
\end{tabular}




\begin{tabular}{|llllll|}
\hline \multicolumn{5}{|l}{ Extraction with reagents } & \multicolumn{3}{l}{ Heat Extraction } \\
\hline $26^{\circ}$ & 31 & 32 & 29 & 27 & 26 \\
\hline $27^{\circ}$ & 31 & 31 & 32 & 35 & 30 \\
\hline $28^{\circ}$ & 32 & 27 & 31 & 27 & 35 \\
\hline $29^{\circ}$ & 32 & 29 & 31 & 32 & 37 \\
\hline $30^{\circ}$ & 32 & 26 & 22 & 23 & 25 \\
\hline $31^{\circ}$ & 33 & 31 & 0 & 28 & 0 \\
\hline $32^{\circ}$ & 33 & 32 & 25 & 22 & 20 \\
\hline $33^{\circ}$ & 33 & 0 & 35 & 28 & 27 \\
\hline $34^{\circ}$ & 33 & 27 & 26 & 23 & 31 \\
\hline $35^{\circ}$ & 33 & 25 & 30 & 22 & 28 \\
\hline $36^{\circ}$ & 33 & 30 & 29 & 0 & 28 \\
\hline $37^{\circ}$ & 33 & 27 & 26 & 32 & 26 \\
\hline $38^{\circ}$ & 33 & 31 & 32 & 26 & 26 \\
\hline $39^{\circ}$ & 34 & 29 & 36 & 0 & 0 \\
\hline $40^{\circ}$ & 34 & 31 & 28 & 25 & 31 \\
\hline $41^{\circ}$ & 34 & 37 & 28 & 26 & 36 \\
\hline $42^{\circ}$ & 34 & 36 & 32 & 30 & 0 \\
\hline $43^{\circ}$ & 34 & 30 & 26 & 25 & 0 \\
\hline
\end{tabular}

